\title{
STUDIES UPON THE SIZING QUALITY OF THE ROSIN SIZED PAPER. PART V.
}

\author{
By Gingo Takano.
}

(Received June 25, 1929.)

The abstract of the original paper will appear in the later number of the Journal. (Editon)

\section{ERRATUM}

Vol. 5, No. 7, Page 17, line 5, read XXV for XXIV. 